原 著

\title{
疫学調査データにおける欠損值が解析結果に与える影響の評価
}

早山陽子* · 山本健久 · 小林創太 ·村井清和 · 筒井俊之

国立研究開発法人 農業・食品産業技術総合研究機構

動物衛生研究部門 ウイルス・疫学研究領域

\section{Evaluation of the Effect of Missing Data on the Estimation of the Analysis : A Simulation Example Using Epidemiological Survey Data}

\author{
Yoko HAYAMA, Takehisa YAMAMOTO, Sota KOBAYASHI, Kiyokazu MURAI and Toshiyuki TSUTSUI \\ Viral Disease and Epidemiology Research Division, National Institute of Animal Health, \\ National Agriculture and Food Research Organization \\ (Received 31 Mar, 2016/Accepted 16 Jul, 2016)
}

\begin{abstract}
Summary
Missing data hinders epidemiological data analysis as it reduces the statistical power and produces biased estimates. The traditional methods for dealing with missing data, such as list-wise deletion (complete case analysis) and overall mean imputation, are known to produce biased estimations in some situations. To address these limitations, multiple imputation is becoming popular for handling missing data. In this study, a simulated data were analyzed to examine the influence of missing data on the estimates of analysis through comparing list-wise deletion and multiple imputation. For this purpose, an empirical epidemiological survey data concerning farm management practices in 563 dairy farms to investigate risk factors associated with bovine leukemia virus infection were used to create the simulated dataset with missing values.

Missing data mechanisms are classified into 3 categories based on how the probability of missing values relates to the data : (1) missing completely at random (MCAR), the probability of being missing is a completely random event ; (2) missing at random (MAR), the probability of being missing depends only on the observed data ; and (3) not missing at random (NMAR), the probability of being missing depends on unobserved data or a variable which is missing itself. Five missing data scenarios with different missing data mechanisms and varied missing value proportions were examined in this study. For each scenario, 100 simulated datasets were generated from the empirical data. For each simulated dataset, list-wise deletion and multiple imputation were performed, and estimated coefficients regarding bovine leukemia virus infection via logistic regression were compared.

Under any assumption of missing data mechanisms, estimates of coefficients obtained by list-wise deletion showed less precision than those obtained by multiple imputation. Under the MCAR assumption, list-wise deletion produced less precision in estimates as the proportion of missing data was larger, and under the MAR and NMAR assumptions it led to biased estimates. Meanwhile, multiple imputation produced less bias and greater precision under the MCAR and MAR assumptions. However, biased estimates were observed in the results of multiple imputation under the NMAR assumption. This study demonstrated that missing data induced less precision and biased estimates in analyzing epidemiological data and also showed the practical utility of multiple imputation methods to improve the precision of estimation in dealing with missing data.
\end{abstract}

連絡先 : 早山陽子*

国立研究開発法人 農業・食品産業技術総合研究機構

動物衛生研究部門 ウイルス・疫学研究領域

干305-0856 茨城県つくば市観音台 3-1-5

Tel \& Fax : 029-838-7769

E-mail : hayama@affrc.go.jp
Keywords : missing data, multiple imputation, MCAR, MAR, NMAR, list-wise deletion, epidemiological data 


\section{要 約}

欠損値のあるデー夕は, 推定精度や検出力の低下といっ た影響を及ぼす。従来の欠損值処理法であるリストワイズ 法（欠損值除去法）や代入法は推定值にバイアスが生じる 場合があり, 多重代入法が新たな手法として応用されつつ ある。本研究では, 実際の疫学調查デー夕を用いて疑似欠 損デー夕を作出し, 久損值が推定結果に与える影響をリス トワイズ法と多重代入法で検証した。検証には, 牛白血病 の飼養衛生管理に関する既存の疫学調査デー夕を用いた。

欠損值はその発生メカニズムにより, 欠損が完全にラン ダムに発生する MCAR (Missing Completely At Random), 欠損が観察した他の変数と関連する MAR (Missing At Random), 欠損が観測されていない変数や欠損のある変数 自身に関連するNMAR（Not Missing At Random）に分類 される。そこで, 疑似欠損データとして, 久損值発生メカ ニズムと久損值割合が異なる 5 種類のデー夕を調査デー夕 を用いて各 100 セット作出した。疑似欠損データに対して, 2 種類の欠損值処理法を適用してロジスティック回帰分析 を行い, 牛白血病の発生に関連する変数の推定值を比較し た。その結果, リストワイズ法は, 多重代入法よりも推定 值のバラッキが大きく, MAR と NMAR では推定值にバイ アスが生じていた。多重代入法は, MCAR と MAR では推 定值のバラツキ, バイアスともに小さく, 良好な推定精度 を示したが, NMARの場合は推定值にバイアスが生じて いた。

以上から, 久損值による推定結果のバイアスや精度の低 下は，多重代入法により改善が見込まれることが確認され た。

\section{1. 序 文}

欠損值とは, 調査デー夕におけるある調查項目のデータ の久落を意味する。欠損値は, 調査項目の記入漏れや無回 答, 追跡調查における対象者の脱落などによって生じる。 調査デー夕を解析する際, 久損值の存在は, 統計学的な検 出力の低下や, バイアスのある推定結果の発生, デー夕の 代表性の低下, 推定結果の安定性の低下といった影響を及 ぼすことが知られている゙ 。

Rubin は, 観察デー夕の変数と欠損值の発生確率の関係 性から, 久損値の発生メカニズムを 3 種類に分類した ${ }^{15}$ 。 1つ目は, Missing Completely At Random (MCAR) で, 欠 損が完全にランダムに生じるケースである。観測データの 変数のうち, 欠損值がある変数を Z, それ以外の観測デー 夕の変数を X, そして Z の欠損值の有無を示す確率変数 を R (Zが欠損值ならば 1 ，欠損值でなければ 0$)$ とすると, MCAR の場合, Z の欠損値は完全にランダムに発生し, 確
(A) MCAR

(B) MAR
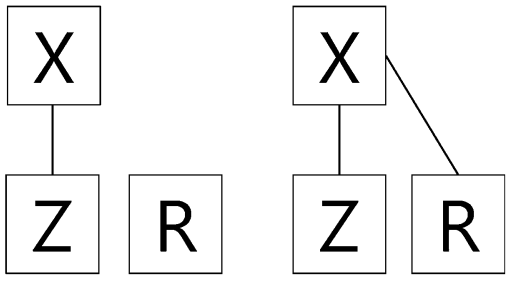

図 1 欠損值発生メカニズムの概念図。Xは観察デー 夕の変数, Z は欠損值のある観察デー夕の変数, $\mathrm{R}$ は Z の欠損值の有無を示す確率変数, W は観 察デー夕に含まれない変数。Enders ${ }^{4)}$ を参考に 改変した。

率変数 $\mathrm{R}$ は変数 $\mathrm{X}$ とも $\mathrm{Z}$ とも関係がない（図 $1 \mathrm{~A}) 。 2 つ$ 目は, Missing At Radom（MAR）であり，Z の欠損の有無 （すなわち確率変数 R）が, 他の変数 $\mathrm{X}$ と関連しているケー スである (図 1B)。欠損の有無が他の変数と関連している 点が, MCAR と大きな違いである。このとき, 確率変数 $\mathrm{R}$ は他の変数 $\mathrm{X}$ と関連しているが, 変数 $\mathrm{Z}$ 自身とは関係 がない。3つ目は, Not Missing At Random（NMAR 又は MNAR）である。NMAR は，Z の欠損の有無が観察され ていない変数 $\mathrm{W}$ や変数 $\mathrm{Z}$ 自身に関連しているケースであ る(図 1C)。

従来，欠損值を含んだデータセットに対しては，欠損值 のあるデー夕を削除する方法や久損值に単一の值を代入す る方法が久損值の处理法として用いられてきだ)。欠損值 のあるデー夕を削除する方法のうち, リストワイズ法 (List-wise deletion 又は Complete-case analysis) は, 少なく とも 1 つ以上の変数で欠損值を含む個別デー夕は全て除外 して, 完全に観察された個別デー夕のみを用いて分析を行 う。ペアワイズ法 (Pairwise deletion) は, 相関行列などを 求める際に, 組み合わせる 2 変数のいずれかが久損值を持 つ場合にデー夕を除去する方法であり, 変数の組み合わせ に応じて利用できるデータ数は異なる。これらの手法は, デー夕の削除により, デー夕数の減少に伴う検出力の低下 や選択バイアスが生じるお方机がある ${ }^{16)}$ 。代入法には，平 均值代入法や回帰代入法がある。平均值代入法（Personal mean score) は, 久損值のないデータの平均值を欠損值に 代入する方法である。回帰代入法 (Personal regression score 又は Cold-deck imputation）は，欠損值がある変数を被説明 変数に, 被説明変数に影響しそうな变数を説明変数にし て, 単回帰分析や重回帰分析を用いて被説明変数を推定す る統計モデルを作成し，このモデル式を利用して久損部位 の值を推定し, 代入する。近似值代入法 (Hot-deck imputation）は, 久損值を含むデータの属性と近似しているデー 夕の値を代入する。この他, 追跡調査の場合は, 前回の観 
測值やベースライン值を代入する前観測值代入法（Last observation carried forward, LOCF) やベースライン值代入 法 (Baseline observation carried forward, BOCF) がある。こ れらの代入法は, 測定值の不確かさが考慮されておらず, 測定值が過大評価あるいは過小評価されることがあり，推 定值にバイアスが生じるおそれがある ${ }^{2,11}$ 。

近年では, 統計解析ソフトウェアの発展に伴い, 従来の 欠損值処理法に代わり, 多重代入法（Multiple imputation） や完全情報最尤推定法 (Full maximum likelihood method, FIML）が欠損值を含むデー夕解析の主体となりつつあ る ${ }^{18)}$ 。多重代入法は, 久損值を代入したデータセット（疑 似完全データセット）を複数作成し，その結果を統合する ことで, 久損值を含むデータの統計学的推測を行う方法で ある ${ }^{16)}$ 。疑似完全データセットは, まず，欠損值を含まな いデータから久損值を予測する多変量回帰モデルを構築 し, 次に, この回帰モデルの予測值にランダム誤差を加え て久損值を代入するという工程を必要なデータセット数に なるまで繰り返すことで作出する。データセットを複数作 成することによって, 欠損值による推定の不確実性を結果 に反映させている点が，単一代入法とは異なる ${ }^{4,11)}$ 。一方, FIML は, 欠損值を考慮した上で最尤推定法を行う分析法 である ${ }^{4,11)}$ 。多重代入法と異なる点は, 多变量回帰モデル ではなく, 共分散構造分析法を用いた因子モデルで統計モ デルを構築することである。多重代入法と FIML はどちら も同等の推定精度を示すことが報告されている ${ }^{3,6)}$ 。実用 的な面では, FIML は共分散構造分析を扱える統計解析ソ フトウェアを用いることになるが，連続変数を分析できる ソフトはいくつかあるものの, カテゴリカル変数を分析で きるソフトウェアは限られている ${ }^{2-4,14)}$ 。多重代入法は, 連 続変数でも, カテゴリカル変数でも対応可能で, Rをはじ め主要な統計ソフトウェアに実装されているので, 汎用性 がある。

欠損值データの問題は, 人の臨床試験の分野では研究が 活発なテーマの 1 つである。米国と欧州の規制当局は, 医 薬品開発の臨床試験での欠損值データの取り扱いについて 報告書を公表している ${ }^{5,12)}$ 。これらの報告書では, 欠損値 データの発生を最小化すること, 久損值データの種類と量 を予測し，それらの扱いを事前に明記すること, 幅広い仮 定に基づいて解析し, 結果の安定性を確認することなどの 欠損值データへの対処法について述べている。日本でも, これらの報告書をもとにして, 臨床試験の欠損值データの 取り扱いについての報告書がとりまとめられている ${ }^{13)}$ 。一 方, 獣医疫学分野では, 欠損值の取り扱いについての検証 はあまり行われておらず，従来のリストワイズ法が多用さ れているが, Dohoo ${ }^{2)}$ は多重代入法による欠損值処理は獣 医疫学分野でも今後有用な手法になるだろうと述べてい
る。そこで, 本研究では, 久損值が分析結果の推定值に与 える影響を評価するため, 実際の疫学調査データから疑似 欠損データを作出することによって, リストワイズ法と多 重代入法による分析結果の違いを比較した。

\section{2. 材料と方法}

\section{1 使用する疫学調査データ}

欠損值の影響の評価には, 牛白血病のリスク要因を分析 するために，酪農場 563 戸（陽性 441 戸，陰性 122 戸）に 対して実施した飼養衛生管理に関する既存の疫学調査デー 夕を用いた ${ }^{9)}$ 。調査項目は, 導入の有無, 育成預託の有無, 牛舎形態（放し飼い又はつなぎ飼い）, アブの生息評価（全 く〜ほとんどいない, 時々〜しばしば, 非常に多い), ア ブの有無, 除角の実施, 除角器具の消毒, 除角後の止血, 耳標器具の消毒, 鼻環の装着, 鼻環装着後の止血, 断尾の 実施, 断尾器具の消毒, 断尾後の止血, 直検手袋の 1 頭 1 枚の実施, 注射時の 1 頭 1 針の実施, 注射時の 1 頭 1 シリ ンジの実施, 注射時の 1 頭 1 針 1 シリンジの実施, 分娩直 後からの母牛と子牛の分離飼育の実施, 初乳の給与, 加熱 処理初乳の給与, プール初乳の給与, 子牛同士の接触の有 無, 子牛の成牛との接触の有無, プール常乳の給与, 過去 5 年間の発生の有無の全 26 項目からなり, これらのうち 単変量解析で $\mathrm{p}<0.05$ となった $5 つ の$ 項目, 「導入の有無」, 「育成預託の有無」,「牛舎形態（放し飼い又はつなぎ飼い）」, 「子牛の成牛との接触の有無」及び「過去 5 年間の発生の 有無」を本研究で検討する変数とした（表 1)。このデー 夕は欠損值のない完全データであり, このデータを「オリ ジナルデータ」とした。

\section{2 疑似欠損データの作出}

オリジナルデータを用いて, 久損值の発生メカニズムと 欠損值の割合が異なる 5 種類の疑似欠損データをそれぞれ 100 セット作出した。MCARの疑似欠損データでは, 各変 数に欠損值をランダムに発生させた。欠損值の割合は, 各 変数の $1 \%, 5 \%$ 及び $10 \%$ としたものを作出した（MCAR1, MCAR5, MCAR10)。MAR の疑似欠損データは, 「牛舎形 態の欠損值」を「過去 5 年以内の発生の有無」と関連があ るように発生させた。すなわち，5 年以内に摘発があった 農場ほど牛舎形態に欠損值が出やすいように重み付けをし て欠損值を発生させた。その他の変数については, ランダ ムに久損值を発生させた。各変数の欠損值の割合は，5\% とした (MAR5)。NMAR の疑似欠損データは,「牛舎形態 の欠損值」が「牛舎形態」と「過去 5 年以内の発生の有無」 に関連があるように発生させた。すなわち，「牛舎形態が つなぎであること」あるいは「過去 5 年以内に摘発があっ た」農場ほど牛舍形態に欠損值が出やすいように重み付け をして欠損值を発生させた。その他の変数については, ラ 
表 1 オリジナルデータの多変量ロジスティック回帰分析の結果

\begin{tabular}{|c|c|c|c|c|c|c|}
\hline \multirow{2}{*}{ 変数 } & \multirow{2}{*}{ 区分 } & \multirow{2}{*}{ 係数の推定值 } & \multicolumn{2}{|c|}{ 95\% 信頼区間 } & \multirow{2}{*}{ 標準誤差 } & \multirow{2}{*}{$\mathrm{p}$ 值 } \\
\hline & & & 下限 & 上限 & & \\
\hline \multirow[t]{2}{*}{ 導入 } & なし & - & & & & \\
\hline & あり & 1.5247 & 1.0763 & 1.9915 & 0.2330 & $<0.001$ \\
\hline \multirow[t]{2}{*}{ 育成預託 } & なし & - & & & & \\
\hline & あり & 0.5181 & 0.0073 & 1.0550 & 0.2664 & 0.0518 \\
\hline \multirow[t]{2}{*}{ 牛舎形態 } & つなぎ & - & & & & \\
\hline & 放し飼い & 0.4719 & -0.1409 & 1.1354 & 0.3236 & 0.1448 \\
\hline \multirow[t]{2}{*}{ 子牛と成牛との接触 } & なし & - & & & & \\
\hline & あり & 0.7863 & 0.0903 & 1.5719 & 0.3744 & 0.0357 \\
\hline \multirow[t]{2}{*}{ 過去 5 年以内の発生 } & なし & - & & & & \\
\hline & あり & 3.2163 & 1.6763 & 6.0971 & 1.0174 & 0.0016 \\
\hline
\end{tabular}

ンダムに久損值を発生させた。各変数の欠損值の割合は $5 \%$ とした（NMAR5)。

\section{3 欠損値処理法による推定結果の比較}

作出した全ての疑似欠損データに対して, リストワイズ 法と多重代入法を適用し, 牛白血病の感染（陽性ならば 1 , 陰性ならば 0）に関連する要因をロジスティック回㷌分析 により解析した。両手法における係数の推定值の精度 (precision)，すなわちバラツキを評価するため，各係数の 推定值の分布をボックスプロットで表示した。また，推定 值の正確度 (accuracy), すなわちバイアスを評価するため, オリジナルデータの推定值からのバイアスの指標となる パーセントバイアス ${ }^{10)}$ と, 久損值データの推定值がオリ ジナルデータの推定值の $95 \%$ 信頼区間に含まれる割合を 求めた。全ての解析は R で行い, 多重代入法には mice packageの mice 関数を用いた。多重代入法では, データセッ トに含まれる 5 つの変数を用いて欠損值を代入した。変数 は全て二值変数であったため, 久損值の代入方法はロジス ティック回帰法 (mice 関数, logreg オプション) を用い, 作成する疑似完全デー夕数は 20 セットとした ${ }^{4,19)}$ 。

\section{3. 成 績}

5 種類の疑似欠損データ（各 100 セット）について, 久 損值があった農場の割合は中央值で, MCAR1 が 5\%（27/ 563), MCAR5 が 23\% (127/563), MCAR10 が 41\%（230/ 563), MAR5 が 22\%（126/563）及び NMAR5 が 23\%（128/ 563）だった。

リストワイズ法と多重代入法で推定された係数の分布を 比較したところ, いずれの変数, いずれの欠損值発生メカ ニズムにおいても, リストワイズ法は多重代入法よりも係 数の推定值のバラッキが大きかった（図 2)。MCAR では 欠損值の割合が多くなるほど, リストワイズ法では推定值
のバラッキが大きくなり，オリジナルデータの $95 \%$ 信頼 区間に含まれる割合が下がった（表 2)。リストワイズ法 の場合,「過去 5 年間の発生の有無」に関する係数の推定 值のバラッキが非常に大きく，特にMCAR10，MAR5 及 びNMAR5 では，オリジナルデータの推定值と大きく乘離 し, 推定值にバイアスが生じていた（表 3）。多重代入法は, MCAR と MAR ではバラッキ，バイアスともに小さく，良 好な推定結果を得た。推定值のオリジナルデー夕からの乘 離は小さく, 多重代入法による推定值のほとんどはオリジ ナルデータの推定值の $95 \%$ 信頼区間に含まれ（表 2)，パー セントバイアスは概ね 5\% 以内に収まった（表 3)。NMAR の場合, リストワイズ法, 多重代入法ともに, 牛舎形態の 係数の推定值がオリジナルデータの推定值から乘離し, パーセントバイアスの值も大きくなり, 推定值が小さくな る方にバイアスがかかっていた（図2，表3）。

\section{4. 考 察}

欠損值の発生メカニズムが MCAR の時, リストワイズ 法では, 久損值の割合が大きくなるにつれて, 推定值のバ ラッキが大きくなった。これは, 久損值のあるデー夕を全 て除去して分析することによって, デー夕数が減少したた めに，推定の精度が下がったことを示している。欠損值の 割合に関する基準は確立されていないが济，明確な根拠は 示されていないものの, Schafer は欠損值の割合が $5 \%$ 未 満であれば大きな影響がないと述べ17), Bennet は欠損值の 割合が $10 \%$ 以上だとバイアスが生じやすいと述べている1)。 したがって， 欠損值の割合が多いデータにリストワイズ法 を使用することは推定の精度に影響を与える可能性がある ことに注意が必要である。

欠損值の発生メカニズムが MCAR であれば, リストワイ ズ法はバイアスのない推定值を与えると言われている2,4)。 

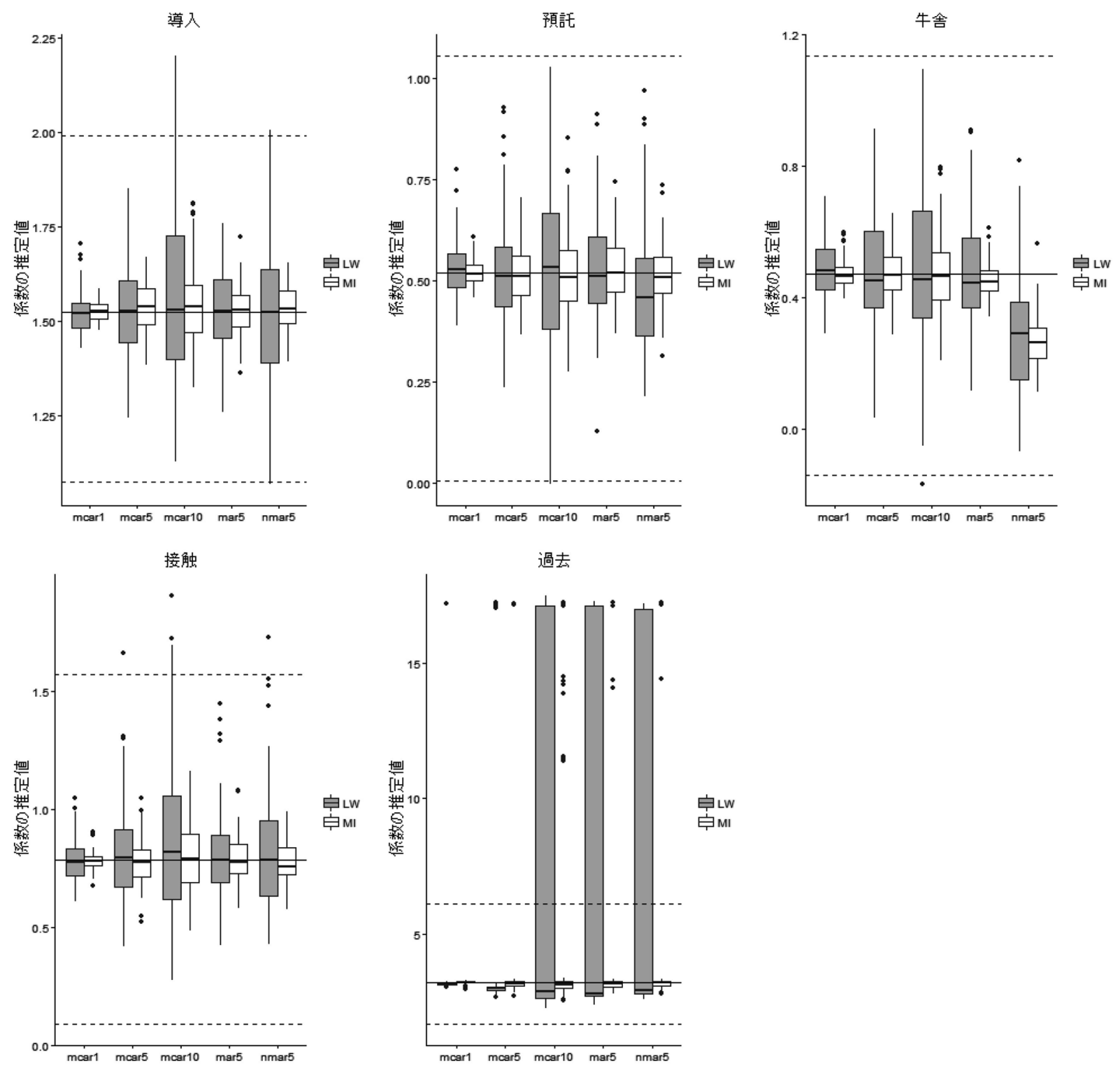

図 2 推定した係数の分布。灰色のボックスプロット（LW）はリストワイズ法の結果を, 白色のボックスプロット (MI) は多重代入法の結果を示す。縦軸（係数の推定值）からの水平線はオリジナルデータの係数の推定值 (実線) と $95 \%$ 信頼区間（点線）を示す。

今回のデータでは, 久損值の割合が少ない MCAR1 と MCAR5 の条件下では, 全ての変数において比較的バイア スが小さい推定值を得ることができた。しかし，MCAR10 の場合, 変数のうち,「過去 5 年以内に摘発があったこと」 については,リストワイズ法では大きな変動を示して抢り， バイアスがかかった推定結果を示していた。この変数につ いては, オリジナルデー夕においても, 他の変数よりも標 準誤差が大きく,推定值の変動が大きい傾向を示していた。 このようなデータで久損が生じた場合, MCARであって も, リストワイズ法の推定值は不安定なものとなり, 推定
の精度と正確性が低下するおそれがあることを示してい る。

一方, 多重代入法は, MCAR と MAR において係数のバ ラッキとバイアスが小さく, オリジナルデータの推定值と 近い推定結果を示した。上述したように，リストワイズ法 では,「過去 5 年以内に摘発があったこと」については, MCAR10 と MAR5 で変動の大きい推定結果だったが, 多 重代入法ではこの変数に関しても精度の高い推定結果を得 ることができた。MCARやMAR の条件下で多重代入法に よって安定した推定した結果を得られることは, 先行研究 
表 2 欠損処理法の係数の推定值がオリジナルデータの係数の $95 \%$ 信頼区間に含まれる割合（\%)

\begin{tabular}{lrrrrr}
\hline 欠損值メカニズム & 導入の有無 & 育成預託の有無 & 牛舎形態 & 子牛の成牛との接触 & 過去の発生歴 \\
\hline リストワイ゙法 & & & & & \\
mcar1 & 100 & 100 & 100 & 100 & 98 \\
mcar5 & 100 & 100 & 100 & 99 & 85 \\
mcar10 & 95 & 99 & 99 & 97 & 60 \\
mar5 & 100 & 100 & 100 & 100 & 62 \\
nmar5 & 98 & 100 & 100 & 99 & 66 \\
多重代入法 & & & & & \\
mcar1 & 100 & 100 & 100 & 100 & 100 \\
mcar5 & 100 & 100 & 100 & 100 & 97 \\
mcar10 & 100 & 100 & 100 & 100 & 89 \\
mar5 & 100 & 100 & 100 & 100 & 95 \\
nmar5 & 100 & 100 & 100 & 100 & 96 \\
\hline
\end{tabular}

表 3 推定した係数のパーセントバイアスの平均值（\%)

\begin{tabular}{lrrrrr}
\hline 欠損值メカニズム & 導入の有無 & 育成預託の有無 & 牛舎形態 & 子牛の成牛との接触 & 過去の発生歴 \\
\hline リストヷ゙法 & & & & & \\
mcar1 & -0.1438 & 1.5771 & 1.6491 & -1.6162 & -1.6392 \\
mcar5 & 0.2811 & -1.1204 & -4.1640 & 1.0372 & -7.3277 \\
mcar10 & 0.3779 & 2.9359 & -3.8063 & 4.1682 & $\mathbf{- 1 1 . 0 8 3 2}$ \\
mar5 & 0.1956 & -1.3259 & -5.7574 & -0.1820 & $\mathbf{- 1 2 . 5 8 0 1}$ \\
nmar5 & -0.0119 & -11.7182 & $\mathbf{- 3 8 . 4 4 8 7}$ & -0.0172 & -9.7544 \\
多重代入法 & & & & & \\
mcar1 & 0.1537 & -0.0684 & -1.7614 & -0.6152 & -0.0079 \\
mcar5 & 1.0543 & -1.3099 & -1.1717 & -1.2963 & -1.1100 \\
mcar10 & 1.0060 & -1.9705 & -1.5082 & 0.6635 & -2.6058 \\
mar5 & 0.4774 & 0.1574 & -5.2605 & -1.0603 & -1.2724 \\
nmar5 & 0.6239 & -2.0155 & $\mathbf{- 4 4 . 0 7 5 1}$ & -3.5298 & -0.1441 \\
\hline
\end{tabular}

パーセントバイアス $=100 \times\{$ ( 欠損值データの推定值-オリジナルデータの推定值)/オリジナルデータの推定值 $\}$

パーセントバイアスが $0 \%$ に近いほど，欠損值データの係数值がオリジナルデータに近いことを示す。

パーセントバイアスが負の值の時は過小に，正のときは過大にバイアスがかかっていることを示す。

特にバイアスが大きいもの（-10\% 以下又は $10 \%$ 以上）を太字で表した。

でも報告されておりり $り^{2,7)}$, 今回の研究でも同様の結果を示 すことができた。

NMAR の疑似欠損データは, 「牛舎形態の欠損值」が「牛 舍形態」と「過去 5 年以内の発生の有無」に関連があるよ うに発生させた。そのため, 今回の分析では, リストワイ ズ法, 多重代入法ともに,「牛舎形態」の係数でバイアス のかかった推定結果となった。多重代入法は, MCARや MAR では良好な推定結果を示したが，NMAR ではうまく 推定できないことを示している。欠損值の発生メカニズム の中でも, NMAR は観測されていない要因や欠損のある 変数自身に関連して久損が生じるという複雑なメカニズム
である。そのため, 欠損デー夕を除去するリストワイズ法 や観察デー夕を元に久損值を補完する代入法では, 推定值 のバイアスを除ききれない ${ }^{2,11,16)}$ 。このため, NMARの解 析手法には, 選択モデル (selection model) やパターン混 合モデル (pattern mixture model) を用いることが多い4)。 いずれの手法も，プロセスは異なるものの，デー夕と欠損 值が起こる確率の同時分布を仮定して分析を行うが, 久損 值が起こる確率に検証不能な強い仮定を用いる必要がある ことから，十分な感度分析を行った上での結果の解釈が必 要であるとされている ${ }^{4)}$ 。この他にも, 補助変数を加える ことによって, NMARの条件をMAR に変換し, 多重代入 
法や FIML を適用する手法もある ${ }^{4)}$ 。この手法では, 分析 の対象として直接関心がない变数である補助変数を用意 し, 補助変数と欠損值の発生確率を関連づけることで, 久 損值の発生メカニズムを NMAR から MARの状態に変換 する。補助変数には, 欠損值の有無と相関が高い変数を用 いることが多い。NMAR の解析手法は, 臨床試験の分野 で研究が盛んな分野であり, 詳細は参考文献を参照された $\omega^{4)}$ 。

本研究では, 既存の疫学調査デー夕を用いて, 久損值が 解析結果の推定值に与える影響を評価した。欠損值を扱う にあたってまず重要なことは, 調査計画の段階で,「久損 值を出さない」という工夫をすることである去。このた めには, 調査項目のアンケートのデザインや, 調查対象の 追跡方法について, 念入りな計画を立てることが重要であ る。次に, やむを得ず生じた欠損值を処理する場合, 従来 のリストワイズ法は MCARによる久損で, 久損值が少な ければ適用可能であるものの, MCAR で欠損值が多い場 合や，MAR や NMAR が想定される場合は適用は好ましく ない。今回の結果では, MCAR と MARの条件下における 多重代入法の有効性を示すことができた。疫学調査におい てより適切な解析結果を得るためには, 欠損值を少なくす る調査デザインを計画するとともに, 欠損值の取り扱いを 含めた解析手法についても検討していくことが重要であ る。

\section{謝 辞}

本研究は, 科学研究費助成事業「離散変量に起因する不 確かさの評価と標準的リスク対応の確立一食品微生物規格 への反映（課題番号 25280009）」で実施した。

\section{引用文献}

1) Bennett, D.A. : How can I deal with missing data in my study? Aust. N. Z. J. Public Health., 25, 464-469, 2001.

2) Dohoo, I.R. : Dealing with deficient and missing data. Prev. Vet. Med., 122, 221-228, 2015.

3) Dong, Y. and Peng, C.Y. : Principled missing data methods for researchers. Springerplus., 2, 222, 2013.

4) Enders, C.K. : Applied missing data analysis. The Guilford press, New York, 2010

5) European Medicines Agency : Guideline on missing data in confirmatory clinical trials, 2010, Available at : http://www. ema.europa.eu/docs/en_GB/document_library/Scientific_ guideline/2010/09/WC500096793.pdf (Accessed March 29, 2016)
6) Graham, J.W., Olchowski, A.E. and Gilreath, T.D. : How many imputations are really needed? Some practical clarifications of multiple imputation theory. Prev. Sci., 8, 206$213,2007$.

7) Groenwold, R.H. et al. : Dealing with missing outcome data in randomized trials and observational studies. Am. J. Epidemiol., 175, 210-217, 2012.

8) Kang, H. : The prevention and handling of the missing data. Korean. J. Anesthesiol., 64, 402-406, 2013.

9) Kobayashi, S. et al. : Analysis of risk factors associated with bovine leukemia virus seropositivity within dairy and beef breeding farms in Japan : a nationwide survey. Res. Vet. Sci., 96, 47-53, 2014.

10) Moriasi, D.N. et al. : Model evaluation guidelines for systematic quantification of accuracy in watershed simulations. Trans. ASABE., 50, 885-900, 2007.

11）村山航：欠損データ分析 (missing data analysis) 一完 全情報最尤推定法と多重代入法一，2011（in Japanese）, Available at : http://koumurayama.com/koujapanese/missing _data.pdf(Accessed March 29, 2016)

12) National Research Council : The prevention and treatment of missing data in clinical trials, 2010, Available at : http:// www.nap.edu/catalog/12955/the-prevention-and-treatmentof-missing-data-in-clinical-trials (Accessed March 29, 2016)

13）日本製薬工業協会：臨床試験の欠測データの取り扱い に関する最近の展開と今後の課題について，2014（in Japanese), Available at : http://www.jpma.or.jp/information/ evaluation/allotment/pdf/data_140704_1.pdf (Accessed March 29, 2016)

14) Peng, C.Y.J. and Zhu, J. : Comparison of two approaches for handling missing covariates in logistic regression. Educ. Psychol. Meas., 68, 58-77, 2008.

15) Rubin, D.B. : Inference and missing data. Biometrika, 63, 581-592, 1976.

16) Rubin, D.B. : Multiple Imputation for Nonresponse in Surveys. Wiley,. New York, 1987.

17) Schafer, J.L. : Multiple imputation : a primer. Stat. Methods. Med. Res., 8, 3-15, 1999.

18) Schafer, J.L. and Graham, J.W. : Missing data : our view of the state of the art. Psychol. Methods., 7, 147-177, 2002.

19) Van Buuren, S. and Groothuis-Oudshoorn, K. : mice : Multivariate Imputation by Chained Equations in R. J.Stat. Softw., 45, 1-67, 2011. 